gjemte blant annet datterens tøydukke under et laken og så hvordan hun reagerte. Hun lette ikke etter dukken før hun ble 6-8 måneder gammel. Piaget konkluderte at spedbarnet mangler det han kalte «objektpermanens» frem til denne alderen, dvs. barnet forstår ikke at gjenstander fortsetter å eksistere selv om det ikke ser dem eller sanser dem på annen måte. Han observerte videre at hvis barnet har funnet et objekt i posisjon $\mathrm{A}$, vil det senere fortsette å lete etter objektet der, selv om det like forut så at objektet ble flyttet til posisjon B. Observasjoner av en rekke slike «A, ikke $\mathrm{B}$ »-feil ledet Piaget til hypotesen om at objekter kan representeres først når barnet har handlet i forhold til dem på en koordinert måte og internalisert konsekvensene av disse handlingene. Det skjer ifølge Piaget først når barnet er omkring halvannet år gammelt.

De siste 30 års forskning på området har i stadig økende grad satt spørsmålstegn ved mange av hans konklusjoner. Et kjernepunkt i kritikken knytter seg til Piagets bruk av barnets søkeatferd som indikator på dets kunnskap om den fysiske verden. I ett forsøk ble spedbarn i et mørklagt rom filmet med infrarødt kamera. Det viste seg at de strakte hånden mot posisjonen hvor de tidligere hadde observert en gjenstand selv om de ikke lenger så den. Forskerne konkluderte at det var det å søke etter objektet, snarere enn å representere det, som bød på problemer i Piagets fors $ø$. Nyere studier tyder på at manglende modning av dorsale laterale prefrontale cortex, som blant annet innebærer sviktende inhibitorisk kontroll, kan ligge bak feilsøkingen.

I utviklingspsykologien har man nå i stor utstrekning erstattet barnets søkeatferd som indikator med dets synsatferd. I et kjent forsøk viste Baillargeon og medarbeidere at fem måneder gamle barn så betydelig lenger på hendelser som ikke skulle kunne finne sted (f.eks. at en gjenstand beveget seg gjennom en annen som om denne ikke fantes) enn på hendelser som kunne forventes. Dette og en rekke liknende forsøk står i klar motsetning til Piagets hypoteser om spedbarnets objektforståelse, som ser ut til å være operativ langt tidligere enn han antok.

På bakgrunn av disse og liknende funn har Elizabeth Spelke lansert den såkalte kjernekunnskapshypotesen (core knowledge, CK), som er blitt til en dominant teori om objektkunnskapens opprinnelse. Hun påstår at det voksne menneskets kunnskap om den fysiske verden beror på medfødte, erfaringsuavhengige prinsipper for resonnering om ikke-levende fysiske gjenstander og om bevegelse. CK-hypotesen skiller seg fra Piagets konstruktivistiske tilnærming ved å legge langt mindre vekt på erfaringens betydning for både den tidlige og den voksne objektkunnskapen.

I denne utgivelsen gjøres det rede for den pågående forskningen på dette spennende området. Forskningen er tverrfaglig, med bidrag fra utviklingspsykologi, komparativ psykologi, synsforskning og kognitiv nevrovitenskap. Tverrfagligheten har sannsynligvis vært en sentral betingelse for den omfattende kunnskapsutviklingen som har funnet sted de siste 30 år.

The origins of object knowledge inneholder viktig empirisk kunnskap med spesiell relevans for psykoterapeuter og alle som arbeider klinisk med barn. Den belyser blant annet det hyppig diskuterte spørsmålet om når barnets oppfatning om skikkelsen som nærer det endres fra «sammenhengende objekt» til «objekt med morliknende egenskaper» og videre til «min mor».

\section{Erik Falkum}

Avdeling for forskning og fagutvikling

Klinikk for psykisk helse

Oslo universitetssykehus, Aker

\section{Feilsøking - nå også i psykoterapi!}

Beck JS.

Udfordringer i kognitiv terapi

Hvad gør man, når standardmetodene ikke virker. 344 s, ill. København: Akademisk Forlag, 2009. Pris DKK 349

ISBN 978-87-500-4072-9

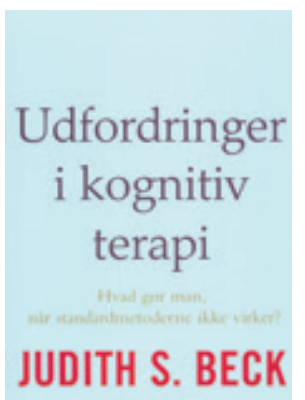

Systemer for monitorering av psykoterapiprosesser er kommet for å bli, det gjelder innen så vel individualsom familieterapi. Denne tendensen hilses velkommen (som rimelig kan være) av bevil-

gende og administrerende myndigheter innen psykisk helsevern. Grunnen er at terapeut og pasient $i$ en tidlig fase av terapien kan få signaler om hvorvidt den går i ønsket retning eller ikke. Hvis den ikke gjør det, vil terapeuten få beskjed om å gjøre noe annet enn den valgte strategien - altså en form for feilsøking med tilhørende beskjed om at terapiopplegget må endres. Forskning viser lovende resultater hva gjelder positivt utfall for og redusert varighet av terapier. Ved Modum Bad foregår det, i samarbeid med andre enheter, for tiden planlegging av denne type prosjekter både for polikliniske pasienter og for innlagte par/familier.

Den amerikanske psykologen Judith Beck (f. 1954) har med denne utgivelsen gitt et solid bidrag til dette feltet ved å sette søkelyset på hvilke utfordringer som møter terapeuten når ikke terapien går som den skal. Hun nøyer seg ikke bare med «feilsøking», men kommer også med relativt detaljerte beskrivelser av hva som bør gjøres (belyst ved tallrike instruktive kliniske eksempler) når «feilen» er identifisert. Selv om hun primært adresserer «feilsøking» innen det kognitive terapifeltet, kan de første seks av de 13 kapitlene ha gyldighet for enhver form for terapi. Det handler om identifisering av behandlingsproblemer (kapittel 1), bevisstgjøring omkring kasusformuleringen hos pasienter med spesielt utfordrende og komplekse problemer (kapittel 2), terapeutiske utfordringer overfor pasienter med personlighetsforstyrrelser (kapittel 3), utvikling og bruk av den terapeutiske allianse (kapittel 4), problemer i den terapeutiske relasjon (kapittel 5) og om terapeuters eventuelle dysfunksjonelle reaksjoner på sine pasienter (kapittel 6).

Ved å ta for seg disse temaer så omfattende som forfatteren gjør her, bidrar hun til å bygge broer og utvide veier mellom den tradisjonelle kognitive teori og terapiutforming og andre terapiretninger, spesielt den psykodynamiske. En så grundig vektlegging av den terapeutiske relasjon er svært godt nytt fra en så toneangivende person innen den kognitive leir, og den brede omtalen av terapeutens mulige uhensiktsmessige eller destruktive reaksjoner overfor pasientene har en klar parallell til motoverføringstematikken i den psykodynamiske språkbruk.

I denne sammenheng berører hun et annet tema som for tiden er på dagsordenen innen bl.a. legekretser, nemlig legers (inkludert terapeuters) egenomsorg som en nødvendighet for å gjøre godt klinisk arbeid og dermed unngå dysfunksjonelle reaksjoner.

De siste sju kapitlene er viet mer spesifikke kognitive elementer - så som målformulering, strukturering av terapitimene, hjemmelekser mellom timene, identifisering av kognisjoner og kjerneoverbevisninger (skjemaer) m.m.

Med tiltalende layout og pedagogisk oppbygning (i dansk oversettelse) der forfatteren øser av sin solide kliniske erfaring, er denne utgivelsen et nyttig bidrag og et modig innspill i psykoterapilitteraturen med omtale av temaer som for noen nok kan være provoserende. Noe som imidlertid savnes er en mer omfattende behandling av kontraindikasjoner for denne terapiformen, som er så sterkt basert på problemløsning, utover den halve siden (s. 232) som omhandler når det kan være viktig ikke å løse problemer.

Udfordringer $i$ kognitiv terapi anbefales for alle som jobber psykoterapeutisk, spesielt gjelder det de første seks kapitlene. Boken kan med fordel settes på pensumlisten for utdanningsprogrammer både innenfor og utenfor den kognitive leir.

\section{Tore Gude}

Modum Bad

og

Avdeling for atferdsfag

Universitetet i Oslo 